\title{
Ancillary Services in Honduras, Regulatory Framework and Proposals for Its Development in the System
}

\section{Servicios Complementarios en Honduras, Marco Regulatorio y \\ Propuestas para su Implementación en el Sistema}

\author{
Jorge ANdrés PÉreZ ${ }^{1}$ | Ellis MoIsÉs REYes ${ }^{2}$ | TANNIA KARINA Vindel ${ }^{3}$
}

Recibido: 18 de febrero de 2019/ Aceptado: 15 de junio de 2019

The ancillary services are essential in the power Systems operation, historically this services haven't been regulated in any way in Honduras. There have been changes recently into the regulatory framework in the entire electricity sector alongside the large-scale injection of photovoltaic and wind powered centrals in the System. Considering these scenarios, the ancillary services become a necessity in terms of the operation for the power system and the stability associated with it.

In this paper, we analyze the technical and economic aspects related to the frequency control, voltage control and blackstart services, we compare the services provided in different countries and how it is possible to adapt the successful cases to the Honduran power system.

La implementación de servicios complementarios es vital para la operación de un sistema eléctrico, históricamente en Honduras estos servicios no han sido establecidos o regulados de alguna manera. En años recientes debido a la reestructuración legal del sub-sector eléctrico y la reciente inserción de sistema eólicos y fotovoltaicos a gran escala, es necesaria la regulación de estos servicios para garantizar la operación del sistema y las interconexiones existentes de formasegura y eficiente.

En el artículo se estudian los aspectos técnicos y económicos de servicios relacionados acontrol de frecuencia, tensión, blackstart y servicios de almacenamiento de energía y se proponen mecanismos de regulación para una futura elaboración de un código de red nacional.

\section{KEYWORDS}

Ancillary Services, Honduras, Regulatory Framework, Frequency

Control, Voltage Control, Blackstart.

\section{PALABRAS CLAVES}

Servicios complementarios, Honduras, Marco Regulatorio, Control de Frecuencia, Control de Voltaje, Blackstart.

PACS

89.20.Kk, 89.90.+n
${ }^{1}$ Escuela de Física, Facultad de Ciencias,

Universidad Nacional Autónoma de Honduras email: jperezm@unah.edu.hn

${ }^{2}$ Departamento de Ingeniería Eléctrica,

Facultad de Ingeniería , Universidad Nacional Autónoma de Honduras email: ellis.reyes@unah.hn

${ }^{3}$ Departamento de Ingeniería Eléctrica, Facultad de Ingeniería , Universidad Nacional Autónoma de Honduras email: tannia.vindel@unah.edu.hn 


\section{I | INTRODUCTION}

There have been changes in the regulatory framework in the Honduran electricity industry. These changes include the management in the electricity market, the most important change is that now is an open market, looking up to the system becoming a horizontally integrated one instead of a vertically integrated market.

Also in the recent years, the penetration of a large amount of renewable power centrals (mainly photovoltaic and wind) had have a significant impact on the reliability and quality of the overall system. Taking these scenarios into consideration we need to analyze the current situation for the ancillary services in the country and the specific regulations for it in the local scenario and the regional situation. We made a comparison with other scenarios for different countries considering the economic and technical aspects. The main objective is to give suggestions for the technical aspects in the network code that is needed in the system.

\section{I ELECTRICAL SUB-SECTOR IN HONDURAS}

In June 2018 in the National Interconnected System (SIN) there is presence of six technologies for energy conversion. The total amount of installed power is 2605.71 MW and is noticeable the high dependence on non-renewable sources like diesel or bunker fuel. This behavior has changed in the past few years, as we mentioned before there has been a large-scale injection of renewable and intermittent energy sources (Congreso Nacional, 2007).

Table 1: Installed capacity on June 2018. ENEE 2007-2018)

\begin{tabular}{|cccc|}
\hline$N^{\circ}$ & Technology & Power (MW) & Percentage (\%) \\
\hline 1 & Hydro-power & 685.0 & 26.3 \\
2 & Fossil Fuel & 1000.1 & 38.4 \\
3 & Biomass & 209.7 & 8.0 \\
4 & Wind & 225.0 & 8.6 \\
5 & Photo-voltaic & 450.9 & 17.3 \\
6 & Geothermal & 35.0 & 1.3 \\
\hline & Total & 2605.71 & 100 \\
\hline
\end{tabular}

\section{I Energy Matrix and Injected Energy}

As observed in table 1 the energy matrix in the country is diverse, the installed capacity has grown to keep up to the demand requirements in the system. The growth of the penetration of the different technologies has varied from one to another as shown in table 2 The major participation of the intermittent technologies increases the necessity for the effective application in the voltage and frequency control and the blackstart service as basic ancillary services for the system.

According to the data obtained from ENEE (2007-2018) the increase has been noticeable specially in 2011 with the injection of 100+ MW from wind farms in the system and in 2015 with the injection of 388MW from PV plants. Also, we must consider the new projects that are expected to connect to the 
SIN.

Table 2: Annual growth by type of technology from 2007 to 2017. ENEE (2007-2018)

\begin{tabular}{|c|c|c|c|c|c|c|}
\hline Year & Hydropower (MW) & Fossil Fuel (MW) & Biomass (MW) & Wind (MW) & PV (MW) & Total (MW) \\
\hline 2007 & 519.7 & 980.9 & 67.8 & 0 & 0 & 1568.4 \\
\hline 2008 & 522 & 993.3 & 81.8 & 0 & 0 & 1597.1 \\
\hline 2009 & 526.4 & 992.5 & 91.4 & 0 & 0 & 1610.3 \\
\hline 2010 & 526.4 & 992.5 & 91.4 & 0 & 0 & 1610.3 \\
\hline 2011 & 529.2 & 1005 & 137.5 & 102 & 0 & 1773.7 \\
\hline 2012 & 538.8 & 982.4 & 105.5 & 102 & 0 & 1728.7 \\
\hline 2013 & 558 & 978.6 & 124.3 & 102 & 0 & 1762.9 \\
\hline 2014 & 623.7 & 978.6 & 142.3 & 152 & 0 & 1896.6 \\
\hline 2015 & 631.5 & 909.9 & 172.2 & 152 & 388 & 2253.6 \\
\hline 2016 & 680.8 & 911.4 & 164.7 & 175 & 388 & 2319.9 \\
\hline 2017 & 670.4 & 974.9 & 209.7 & 175.0 & 409.0 & 2438.9 \\
\hline
\end{tabular}

\section{0}

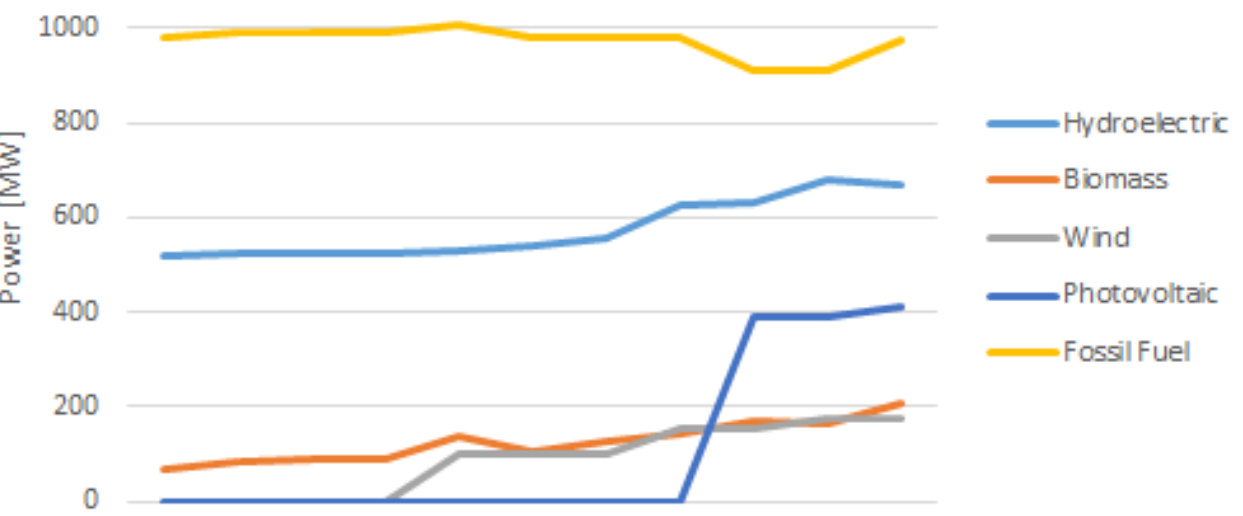

20072008200920102011201220132014201520162017

Figure 1: Annual growth by technologies in the SIN. Data obtained from ENEE 2007-2018)

PV centrals have entered the system in the third quarter of 2015 and the impact of it has been enormous in the system. That year the PV plants injected a total of $394 \mathrm{GWh}$ which represents the $4.4 \%$ of the net energy injected. By 2016 the total amount of energy injected raised to $880.7 \mathrm{GWh}$ that represents a total of $9.7 \%$. The wind plants have a similar percentage of share in the energy distribution, in 2016 they injected a total of $574.1 \mathrm{GWh}$ which represents a $6.4 \%$ in the system. These shares don't seem relevant at first sight, but the reliability on the power grid is a relevant factor to consider when variations on the power output of these power plants becomes significant. 


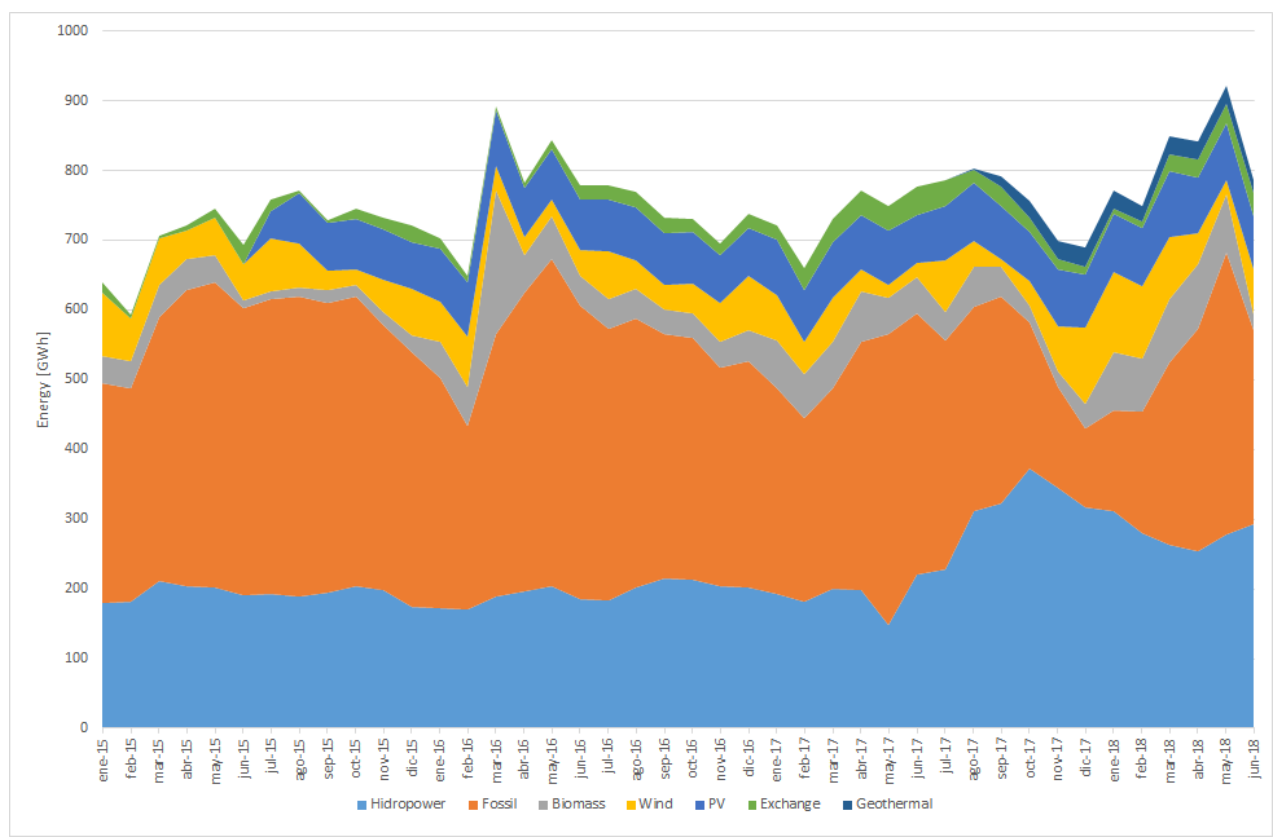

Figure 2: Comparison of energy by type of technology. Data obtained from ENEE (2007-2018)

\section{III | REGULATORY FRAMEWORK}

In 2014 was published the new law for the electricity sector in the country Congreso Nacional (2014), this new act opened the industry to achieve a horizontally integrated market, which changes completely the scenario used before. This new framework allows the participation of private entities in the various stages of the electricity sector such as generation, transmission, distribution and commercialization. The new framework establishes the requirements and restrictions needed in every stage (CREE) 2015c). These stages were responsibility of the National Electric Power Company (ENEE), now ENEE is responsible for the transmission stage and part of the generation system.

\section{I Electricity Regulator Commission}

Within the legal framework approved in 2014, the Electric Industry Regulatory Commission (CREE) was created. This Institution fulfills different tasks like market operator, system operator and to establish technical regulations for all the participants in the sector. In general terms, the functions of the CREE are as follows (Congreso Nacional, 2014), (CREE, 2015b)

1. To guarantee the compliance of the regulations governing the electricity sub-sector

2. Apply sanctions for those who commit infractions

3. Create rules which enhance the application of the law and the performance of the electric sec- tor

4. Give operating licenses for transmission and distribution companies

5. Define the methodology for the calculus of the distribution and transmission rates

6. Supervision of the processes and contracts com- 
panies use to bought energy and power

7. Approve applications from qualified consumers

8. Prevent noncompetitive or monopoly behaviors among the sector participants.

9. Review the technical and economic conditions for the expansion plan of the grid

This Institution has the faculty to create a network code which allows the regulation of the different participants at every level in the electrical sub-sector, said code should specify the technical conditions that participants must fulfill CREE(2015b). For the implementation of ancillary services the regulations must begin in the generation stage, these are the group with greater responsibility in the provision of the services. Regulations then should be extended to transmission and distribution agencies, mostly if it is established that qualified consumers can provide ancillary services.

\section{I National Electric Market (Estate of Current Market)}

Before the reforms to the general law of the electricity industry, the electric market was regulated and controlled by a single institute, the National Electric Energy Company (ENEE). With the opening of the market the System Operation Regulation and Market Administration Regulation was developed which is responsible for defining the functions and responsibilities of the System Operator as well as the obligations and rights of the participants of the national electric market (CREE, 2015c).

The current electric market operates with four market agents, generating companies, distributing companies, marketers and qualified customers. All of them make their purchases in the National Electric Market and qualified customer can participate without the intervention of a marketer or distributor located in national territory. Market agents must be registered and properly authorized by the CREE. As every entity has rights and obligations that must fulfill CREE[(2015a).

- Generation Company: Market agents that generate electricity for sale in the National Electricity Market. Generating companies can be producing agents as long as they meet the requirements set by the regulations. Also users are allowed to install renewable energy generation equipment inside their home for their own consumption and can make injections to the network of the distribution company. This is specified in CREE (2015c) article 4, article 6 and CREE (2017) article 49. No further regulation has been published sience.

- Commercialization Company: Company that perform the commercialization activity and that is unlinked economically of other agents that carry out the activities of generation, transmis- sion and distribution.

- Qualified consumer: A qualified consumer is defined as one whose demand exceeds the value set by the regulatory commission, and has the faculty to purchase electric power and / or power directly from generators and / or marketers, at freely agreed prices with them; Or in the National Electric Market (MEN) or Regional Electric Market (MER).

- System Operator: The main function of the SO is to ensure the continuity and security of the national electricity supply as well as the efficient operation of the generation and transmission facilities through the transactions in the MEN and MER, ensuring compliance with the obligations set out in the law and its regulations.

\section{I Ancillary Services Defined in the System}

The following complementary services are established in the market and operating regulations and it is established that the technical criteria for their implementation will be defined by the technical standard for ancillary services. Regarding the application, it is indicated that all the agents have the obligation to 
contribute to the implementation of these services, within the technical capacity of each participant (CREE, 2015b), (CREE, 2015a), (CREE, 2015c).

In the economic aspect it is indicated that the services of regulation of primary and secondary frequency as well as the control of reactive power and tension will not be remunerated additionally for the provision of the services. Blackstart is indicated to be mandatory and the remuneration would be made considering the additional cost of the service. The characteristics of complementary services and their type of remuneration are summarized in table 3 .

Table 3: Ancillary services established in the regulatory framework.

\begin{tabular}{|c|c|c|}
\hline Service & Technical Description & Nature \\
\hline $\begin{array}{l}\text { Primary Fre- } \\
\text { quency Control }\end{array}$ & $\begin{array}{l}\text { Automatic frequency control per- } \\
\text { formed by the governor on the gen- } \\
\text { erating units which main goal is to } \\
\text { maintain real-time balance between } \\
\text { generation and demand. }\end{array}$ & $\begin{array}{l}\text { Mandatory without additional pay- } \\
\text { ment }\end{array}$ \\
\hline $\begin{array}{l}\text { Secondary Fre- } \\
\text { quency Control }\end{array}$ & $\begin{array}{l}\text { Automatic frequency control per- } \\
\text { formed by the systems Automatic } \\
\text { Generation Control (ACG) to restore } \\
\text { the frequency to its nominal value } \\
\text { and to restore the primary control } \\
\text { reserve on the generating units. }\end{array}$ & $\begin{array}{l}\text { Mandatory without additional pay- } \\
\text { ment }\end{array}$ \\
\hline Cold reserve & $\begin{array}{l}\text { A kind of reserve that would be } \\
\text { ready to start and operate at full load } \\
\text { within } 15 \text { minutes. The goal is to } \\
\text { restore the secondary reserve after } \\
\text { a large-scale disturbance in the sys- } \\
\text { tem. }\end{array}$ & $\begin{array}{l}\text { Mandatory with the option of addi- } \\
\text { tional payment considering starting } \\
\text { and operation cost }\end{array}$ \\
\hline $\begin{array}{l}\text { Automatic load } \\
\text { disconnection }\end{array}$ & $\begin{array}{l}\text { The framework allows the Regional } \\
\text { Operator and the SO to disconnect } \\
\text { specific loads due to low frequency } \\
\text { or voltage issues in the system to } \\
\text { maintain the security and reliability } \\
\text { on the system's operation. }\end{array}$ & $\begin{array}{l}\text { Mandatory without additional pay- } \\
\text { ment }\end{array}$ \\
\hline $\begin{array}{l}\text { Interruptible de- } \\
\text { mand }\end{array}$ & $\begin{array}{l}\text { The SO can propose a methodology } \\
\text { to perform interruptible demand on } \\
\text { specific consumers with previous no- } \\
\text { tification from the SO. This to pre- } \\
\text { vent emergency or critical states of } \\
\text { operation in the system. }\end{array}$ & $\begin{array}{l}\text { Optional and can be remunerated ad- } \\
\text { ditionally from the SO }\end{array}$ \\
\hline $\begin{array}{l}\text { Voltage and reac- } \\
\text { tive power control }\end{array}$ & $\begin{array}{l}\text { The available resources would be } \\
\text { programmed according to technical } \\
\text { criteria to keep the voltage on the } \\
\text { buses in the system within the al- } \\
\text { lowed margins of variation. It is } \\
\text { possible to program generating units } \\
\text { with the minimum cost criteria. }\end{array}$ & $\begin{array}{l}\text { Mandatory without additional pay- } \\
\text { ment }\end{array}$ \\
\hline
\end{tabular}




\begin{tabular}{|l|l|l|}
\hline Blackstart & $\begin{array}{l}\text { It operates after a partial or complete } \\
\text { blackout due to a major disturbance } \\
\text { in the system. The SO must coordi- } \\
\text { nate the generating units to restore } \\
\text { the system to its normal operation } \\
\text { mode. }\end{array}$ & $\begin{array}{l}\text { Mandatory contribution and the } \\
\text { units will be remunerated consider- } \\
\text { ing the additional cost of the service }\end{array}$ \\
\hline
\end{tabular}

\section{I ANCILLARY SERVICES IMPLEMENTATION RECOMMENDATIONS}

As established in the corresponding regulation, the CREE is empowered to develop a network code for the system which at the time of the investigation has not been prepared. As a result, the transition to the operation of the system has not been achieved. Another aspect to consider for the implementation of the network code is that it is not yet defined who will be the system operator.

The lack of a SO makes established regulations not being implemented at the most basic level by the participants of the Interconnected National System (INS), which has a truly devastating effect on the quality of service available. It is considered necessary to take into account the following aspects when developing a network code that allows the proper operation of the INS.

1. The opening of a wholesale market for energy and auxiliary services. Ancillary services are optimally obtained in the daily market, simultaneously with the compensation of the energy market. The daily planning procedure produces the hourly prices of ancillary services with authorized quantities.

2. Establish a regulation reactive power. Some market agents, such as qualified consumers or distribution companies, should not add reactive power to the transmission network at specific times. Establishing two types of offers, for peak hours is the requirement to consume less reactive power than a percentage (between $0 \%$ and $33 \%$ ) of the active power load. For valley hours consists of consuming more reactive power than a percentage (between $0 \%$ and $33 \%$ ) of the active power load.

3. Develop optimum strategic bidding algorithms for the secondary reserve market and simulation models to address studies of AGC operation, including AGC rules of operation and model generating units.

4. From a supportive policy point of view, nowa- days, the regulation of the current management of ancillary services in Honduras has no price rules and does not accurately reflect the real costs and reasonable benefits of ancillary service providers Therefore, to accelerate the construction of the market for ancillary energy services and then to build a unified and unregulated electricity market system in line with national conditions, the formulation of tariff mechanisms and policies that are adapted to the market economy has important practical importance for guaranteeing the rapid and healthy development of the Honduran economy.

5. Improve research on compensation mechanisms for ancillary services. Combined with the actual conditions of the regional electricity networks, it is necessary to explore the basic principles and the compensation application programs and the evaluation of the diverse types of ancillary services. Then carry out the quantitative measurement and comparison between the various options with a reference to the actual operating data of the power system.

Considering the market environment under which this ancillary services can be managed, a summary has been made in the table 4 considering the experiences of other countries (Carvajal, Serrano, \& Arango, 2013), (Rebours, Kirschen, Trotignon, \& Rossignol, 2007), (Andrianesis, Biskas, \& Liberopoulos, 
2011), (Østergaard, 2006), (Miguélez, Cortés, Rodríguez, \& Camino, 2008) and the different market schemes defined in (CREE, 2015c)

Table 4: Remuneration proposal for the ancillary services in the system.

\begin{tabular}{|c|c|c|}
\hline Service & Technical Description & Remuneration Proposal \\
\hline $\begin{array}{l}\text { Primary Fre- } \\
\text { quency Control }\end{array}$ & $\begin{array}{l}\text { Automatic local control that adjust } \\
\text { the power output of the generating } \\
\text { units and demand of controllable } \\
\text { loads to maintain the balance be- } \\
\text { tween generation and demand. This } \\
\text { control opposes to disturbances in } \\
\text { the system's frequency state. This } \\
\text { control is vital to maintain the stabil- } \\
\text { ity on a power system. }\end{array}$ & $\begin{array}{l}\text { Due to the high difficulty on measur- } \\
\text { ing and evaluation on the quality of } \\
\text { the given service, this type of control } \\
\text { becomes mandatory and without ad- } \\
\text { ditional payment from the SO. There } \\
\text { must be policies to promote the in- } \\
\text { vestment in technologies related to } \\
\text { control and measuring equipment. }\end{array}$ \\
\hline $\begin{array}{l}\text { Secondary Fre- } \\
\text { quency Control }\end{array}$ & $\begin{array}{l}\text { It is a centralized automatic control } \\
\text { that adjust the active power output } \\
\text { to restore the frequency to its nomi- } \\
\text { nal value after a disturbance on the } \\
\text { system. }\end{array}$ & $\begin{array}{l}\text { Considering that the generating } \\
\text { units provide the service, it is neces- } \\
\text { sary to establish a secondary reserve } \\
\text { market. The generating units could } \\
\text { present their bids to increase or de- } \\
\text { crease their power output within a } \\
\text { established margin to provide the } \\
\text { service in an hourly basis. }\end{array}$ \\
\hline $\begin{array}{l}\text { Tertiary Fre- } \\
\text { quency Control }\end{array}$ & $\begin{array}{l}\text { It refers to the manual adjustment in } \\
\text { the dispatch and unit commitment of } \\
\text { the generating units. The purpose of } \\
\text { this type of control is to restore the } \\
\text { primary and secondary reserve mar- } \\
\text { gins and to handle congestion on the } \\
\text { transmission system. It can be used } \\
\text { to restore the frequency to its nomi- } \\
\text { nal value in case that the secondary } \\
\text { reserve isn't able to do it. }\end{array}$ & $\begin{array}{l}\text { There must be a tertiary reserve } \\
\text { market that acts only when the sec- } \\
\text { ondary reserves are sold out. Also, } \\
\text { it is necessary to establish the remu- } \\
\text { neration method for the energy dis- } \\
\text { patched in this operation scenario. }\end{array}$ \\
\hline Voltage Control & $\begin{array}{l}\text { The services related to voltage con- } \\
\text { trol are designed to maintain the } \\
\text { voltage on every bus in the system } \\
\text { within the allowed margin of oper- } \\
\text { ation. Equipment like tap-changer } \\
\text { in transformers and capacitor banks } \\
\text { are used to inject reactive power into } \\
\text { the network to maintain such voltage } \\
\text { levels. }\end{array}$ & $\begin{array}{l}\text { Due to the impact of this service, } \\
\text { there must be a minimum capacity } \\
\text { on every generating unit to inject re- } \\
\text { active power. Additional available } \\
\text { reactive power could be offered in a } \\
\text { voltage control market or in an ancil- } \\
\text { lary services market and there could } \\
\text { be remuneration for this additional } \\
\text { reserve margin. }\end{array}$ \\
\hline
\end{tabular}




\begin{tabular}{|c|c|c|}
\hline Blackstart & $\begin{array}{l}\text { This service is provided by generat- } \\
\text { ing units that can start without assis- } \\
\text { tance and inject power into the grid. } \\
\text { This is necessary in case of a major } \\
\text { blackout on the system (partial o to- } \\
\text { tal). This units provide a signal that } \\
\text { must be followed by other smaller } \\
\text { units and control equipment to re- } \\
\text { store the grid's operation state. }\end{array}$ & $\begin{array}{l}\text { An emergency operation and restora- } \\
\text { tion plan is needed for this type of } \\
\text { scenarios and considering that this } \\
\text { scenario is unlikely this plan should } \\
\text { be established by the SO. The addi- } \\
\text { tional payment could be focused on } \\
\text { the investment needed in the special- } \\
\text { ized equipment for the service }\end{array}$ \\
\hline
\end{tabular}

\section{I CONCLUSION}

The current electricity market in Honduras is still in the exploratory phase. Due to factors such as weak network structure, imperfect market management mechanisms, insufficient reserve capacity and a limited level of automatic generation control, the network had been implementing a centralized power dispatch to ensure safe operation without regard to transactions of ancillary services in the service market, which affected the willingness of generation companies to provide ancillary services and, to a certain extent, network support facilities. With the expansion of market-oriented reforms in Honduras in the electricity industry and the creation of different regulations for the safe and economical operation of the electricity system and the decentralization of the Integrated National System and the promotion of renewable energy without clearly defining a structure for the inclusion of ancillary services in the system has caused certain problems in the stability of the system. It is expected that regulation and marketing of ancillary services will inevitably become one of the key objectives of reforms in the future electricity market that during the first period of construction of the ancillary services market, Honduras can adopt a transition mode in which compensation and trading mechanisms are mixed until equilibrium is achieved in the fully traded trading market.

\section{REFERENCIAS}

Andrianesis, P., Biskas, P., \& Liberopoulos, G. (2011). An overview of greece's wholesale electricity market with emphasis on ancillary services. Electric Power Systems Research, 81(8), 1631-1642.

Carvajal, S., Serrano, J., \& Arango, S. (2013). Colombian ancillary services and international connections: Current weaknesses and policy challenges. Energy policy, 52, 770-778.

Congreso Nacional, H. (2007, Octubre). Ley de promoción a la generación de energía eléctrica con recursos renovables.

Congreso Nacional, H. (2014, Mayo). Ley general de la industria eléctrica.

CREE. (2015a, Noviembre). Reglamento de compras de capacidad firme y energía.

CREE. (2015b, Noviembre). Reglamento de la ley general de la industria eléctrica.

CREE. (2015c, Noviembre). Reglamento de operación del sistema y administración del mercado.

CREE. (2017, November). Resolución cree 05-2017.

ENEE, P. (2007-2018). Boletín estadístico (Tech. Rep.). Empresa Nacional de Energía Eléctrica.

Miguélez, E. L., Cortés, I. E., Rodríguez, L. R., \& Camino, G. L. (2008). An overview of ancillary services in spain. Electric Power Systems Research, 78(3), 515-523.

Østergaard, P. A. (2006). Ancillary services and the integration of substantial quantities of wind power. Applied Energy, 83(5), 451-463.

Rebours, Y. G., Kirschen, D. S., Trotignon, M., \& Rossignol, S. (2007). A survey of frequency and voltage control ancillary services—part i: Technical features. IEEE Transactions on power systems, 22(1), 350-357. 